\title{
RESOLUSI KONFLIK PEMBANGUNAN ISLAMIC CENTER DAN MASJID AT-TAQWA MATARAM
}

\author{
Najamudin \\ Kaprodi Komunikasi Penyiaran Islam \\ Fakultas Dakwah dan Ilmu Komunikasi UIN Mataram \\ najamudin82@uinmataram.ac.id
}

\begin{abstract}
The conflict in utilizing the NTB Islamic Center mosque and At-Taqwa Great Mosque gave rise to diverse responses in the community, especially from the Tabligh Jamaah group who previously managed the At-Taqwa Mataram Grand Mosque as the center of its activities. Despite the fact that activities in the Great Mosque have been moved to the Islamic Center, the Mataram Great Mosque is still used as a means by the Tablighi Jamaah. This research is a field research using a qualitative approach. So if you look at it with Scannell's theory of conflict, where conflict is a natural and normal thing that arises because of differences in perception. Therefore, the construction of houses of worship should be based on the principle of how to realize the benefits in life in the world and in the hereafter. Conflict Resolution Against the Conflict of Islamic Center Development and and the use of the nearby Mataram At-Taqwa Mosque (converted into other functions) also reap polemics, mainly because the land status of the mosque is a waqf land for the mosque. Associated with the status of land waqf, then communication efforts are intensive with the interpreter so as not to cause misunderstandings among the apostate families.
\end{abstract}

Keywords: Conflict, Conflict Resolution, Policy. 


\begin{abstract}
Abstrak
Konflik pemanfaatan masjid Islamic Center NTB dan Masjid Raya At-Taqwa memunculkan respons yang beragam di masyarakat, terutama dari kelompok Jamaah Tabligh yang sebelumnya mengelola Masjid Raya At-Taqwa Mataram sebagai pusat kegiatannya. Meskipun pada faktanya kegiatan di Masjid Raya telah dipindahkan ke Islamic Center, Masjid Raya Mataram masih digunakan berkegiataan oleh Jamaah Tabligh. Penelitian ini merupakan penelitian lapangan dengan menggunakan pendekatan kualitatif. Maka jika melihatnya dengan teori Scannell tentang konflik, dimana konflik merupakan suatu hal alami dan normal yang timbul karena perbedaan persepsi. Karena itu seharusnya pembangunan rumah ibadah berorintasi pada prinsip bagaimana mewujudkan kemanfaatan dalam kehidupan di dunia maupun di akhirat. Resolusi Konflik Terhadap Konflik pembangunan Islamic Center dan dan pemanfaatan Masjid At-Taqwa Mataram yang berdekatan tersebut (dialihfungsikan menjadi fungsi lainnya) menuai polemic juga, terutama karena status tanah masjid tersebut sebagai tanah wakaf untuk masjid.Terkait dengan status wakaf tanah, maka upaya komunikasi itensif dengan pihak pewakaf agar tidak menimbulkan kesalah pahaman dari kalangan keluarga pewakaf.
\end{abstract}

Kata Kunci: Konflik, Resolusi Konflik, Kebijakan 


\section{A. Pendahuluan}

Keberadaan suatu masjid bagi masyarakat, khususnya umat Islam menjadi sangat penting, hal ini disebabkan oleh selain dijadikan sebagai tempat sholat berjamaah, masjid juga dijadikan sebagai tempat untuk melaksanakan kegiatan belajar dan mengajar, sebagai balai pertemuan umat Islam untuk membicarakan berbagai permasalahan umat Islam dan kaum muslimin, serta tempat pemersatu yang bisa menghilangkan berbagai fanatisme keaderahan, kesukuan dan kebangsaan yang kemudian diikat oleh ikatan aqidah Islamiyah.

Jika mengacu kepada sejarah perjuanagn Nabi Muhammad, dimana ketika nabi pertama kali tiba sewaktu hijrah dari Makkah ke Madinah yang diikuti oleh kaum Anshar, hal yang pertama kali dilakukan adalah membangun masjid, setelah itu baru kemudian Nabi mempersaudarakan kaum Muhajirin dengan kaum Anshar sebagai penduduk Madinah saat itu.

Dalam perkembangan zaman saat ini, perkembangan fungsi masjid cukup disayangkan, terutama bagaimana sikap kaum muslimin yang dengan semangatnya untuk berlomba-lomba membangun masjid tanpa memperhatikan jarak pembangunannya, antara masjid yang satu dengan masjid lainnya. Tidak jarang ditemukan di daerahdaerah tertentu, seperti di Pulau Lombok, yaitu pulau yang dikenal dengan pulau Seribu Masjid. Lombok disebut sebagai Pulau Seribu Masjid disebabkan oleh karena banyaknya masjid yang bisa ditemukan hamper disetiap dusun, dan bahkan kadang dalam satu dusun, lingkungan ditemukan masjid dengan jarak yang sangat dekat dengan masjid lainnya, belum termasuk di dalamnya mushalla. Banyaknya masjid dan mushalla yang ditemukan hampir di setiap dusun dan lingkungan tersebut seringkali kemudian terkesan akan mengurangi fungsi masjid sebagai pemersatu bagi kaum muslimin, dan bahkan tidak jarang fungsi masjid dalam hal ini beralih fungsi menjadi media memecah persatuan kaum muslimin.

Pada dasarnya Islam melalui ajarannya mensyari'atkan agar membangun masjid atau mushalla di setiap kampung dan menggunakannya sebagai tempat untuk beribadah dan sholat berjamaah, dan setelah itu agar membersihkannya dengan 
memberikan wewangian yang sewajarnya. ${ }^{1}$

Hal ini kemudian dipertegas oleh pendapatnya Fathul Bahri dalam bukunya Ibanah Al-Ahkam jilid III pada halaman 334 yang menegaskan bahwa dalam memahami perintah untuk mendirikan masjid tersebut memiliki maksud boleh mendirikan masjid kecil dan besar disetiap kampung ataupun kota, dengan alasan jika tidak membangun masjid kecil akan terlalu memakan waktu yang lama untuk sampai ke masjid besar bagi orang-orang yang jarak rumahnya dari masjid besar cukup jauh. $^{2}$

Dengan demikian pada dasarnya hadist di atas menjelaskan bahwa pentingnya membangun masjid di satu daerah yang dapat difungsikan sebagai media pemersatu umat dan ukhuwah Islamiyah. Selain itu juga bisa difungsikan sebagai tempat berkumpul berbagai acara keagamaan.

${ }^{1}$ Muhammad Abid Al-Kabisi Abdullah, Hukum Wakaf. Kajian Kontemporer Pertama dan Terlengkap Tentang Fungsi dan Pengelolaan Wakaf serta Penyelesaian Atas Sengketa Wakaf. Ahkam AlWaqf fi Al-Syariah Al-Islamyiah. terj. Ahrul Sani Faturrahman. (Depok: IIMoN Press, 2004), 3-5.

${ }^{2}$ A. Rahman Asyumi, ILMU FIQH. (Jakarta: Proyek Pembinaan Prasarana dan Sarana Perguruan Tinggi Agama Islam/IAIN di Jakarta Direktorat Jenderal Pembinaan Kelembagaan Agama Islam Departemen Agama, 1986), 2-4.
Fakta yang berkembang di tengah masyarakat Pulau Lombok yang familiar disebut juga sebagai Pulau Seribu Masjid, secara lebih khusus yang ada di Kota Mataram. Pembangunan masjid Hubbul Wathan / Islamic Center yang hanya berjarak 20-30 meter dari masjid At-Taqwa Mataram, dimana kedua masjid tersebut digunakan sebagai mana mestinya sebagai tempat ibadah umat Islam. Hanya saja yang cukup disayangkan adalah, ketika pembangunan dan telah difungsikannya masjid Hububul Wathan / Islamic Center menjadikan masjid At-Taqwa Mataram menjadi tidak berfungsi sebagaimana sebelumnya, karena aktvitas keagamaan yang tadinya cukup ramai kemudian berubah seperti saat kondisi sekarang ini yang dapat disaksikan.

Selain itu juga, diantara dampak pembangunan masjik Hubbul Wathan / Islamic Center adalah terjadinya perpecahan antar pengurus dan bahkan kelompok umat Islam yang biasanya bersatu dalam satu masjid meski konflik tersebut kemudian berhasil diredam sehingga tidak menjadi konflik yang berlarut-larut.

Berdasarkan latarbelakang yan telah dipaparkan tersebut, 
maka menarik untuk mengkaji permasalhan tersebut secara mendalam dalam rumusan judul " Konflik dan Resolusi Konflik Pembangunan dan Pemanfaatn Masjid Hubbul Wathan / Islamic Center dengan Masjid At-Taqwa Mataram"

\section{B. Beberapa Perspektif Teori Tentang Konflik Dan Resolusi Konflik Yang Digunakan}

\section{Pengertian Konflik}

Leopod Von Wiese "Suatu proses sosial dimana orang perorangan atau kelompok manusia berusaha untuk memenuhi apa yang menjadi tujuannya dengan jalan menentang pihak lain disertai dengan ancaman dan kekerasan. Duane Ruthhefelbower "Konflik adalah kondisi yang terjadi ketika dua pihak atau lebih menganggap ada perbedaan posisi yang tidak selaras, tidak cukup sumber dan tindakan salahsatu pihak menghalangi, atau mencampuri atau dalam beberapa hal membuat tujuan pihak lain kurang berhasil.

Dari pendapat-pendapat diatas dapat disimpulkan bahwa konflik adalah suatu kondisi dimana dua belah pihak saling berselisih dikarenakanmempunyaitujuanyang berbeda atau karena sebab lain yang menimbulkan tidak harmonisnya suatu hubungan.

\section{Teori Konflik}

Teori-teori yang berkaitan dengan konflik yang akan dikaji:

a. Teori Negosiasi Prinsip

Menganggap bahwa konflik disebabkan oleh posisi-posisi yang tidak selaras dan perbedaan pandangan tentang konflik oleh pihak-pihak yang mengalami konflik. Sasaran yang ingin dicapai teori ini adalah: Pertama, Membantu pihak-pihak yang mengalami konflik untuk memisahkan perasaan pribadi dengan berbagai masalah dan isu, dan memampukan mereka untuk melakukan negosiasi berdasarkan kepentingan-kepentingan mereka daripada posisi tertentu yang sudah tetap. Kedua Melancarkan proses pencapaian kesepakatan yang menguntungkan kedua belah pihak atau semua pihak. ${ }^{3}$

b. Penyebab Konflik

Konflik muncul karena ada kondisi yang melatar - belakanginya (antecedent conditions). Kondisi tersebut, yang disebut juga sebagai sumber terjadinya konflik, terdiri dari tiga ketegori, yaitu: komunikasi, struktur, dan variabel pribadi.

1) Komunikasi

${ }^{3}$ RoziSyafuan, dkk. Kekerasan Komunal: Anatomi dan Resolusi Konflik di Indonesia, (Yogyakarta: Pustaka Pelajar, 2006), 10. 
Komunikasi yang buruk, dalam arti komunikasi yang menimbulkan kesalah - pahaman antara pihakpihak yang terlibat, dapat menjadi sumberkonflik. Suatu hasilpenelitian menunjukkan bahwa kesulitan semantik, pertukaran informasi yang tidak cukup, dan gangguan dalam saluran komunikasi merupakan penghalang terhadap komunikasi dan menjadi kondisi anteseden untuk terciptanya konflik.

\section{2) Struktur.}

Istilah struktur dalam konteks ini digunakan dalam artian yang mencakup: ukuran (kelompok), derajat spesialisasi yang diberikan kepada anggota kelompok, kejelasan jurisdiksi (wilayah kerja), kecocokan antara tujuan anggota dengan tujuan kelompok, gaya kepemimpinan, sistem imbalan, dan derajat ketergantungan antara kelompok. Penelitian menunjukkan bahwa ukuran kelompok dan derajat spesialisasi merupakan variabel yang mendorong terjadinya konflik. Makin besar kelompok, dan makin terspesialisasi kegiatannya, maka semakin besar pula kemungkinan terjadinya konflik.

3) Variabel Pribadi

Sumber konflik lainnya yang potensial adalah faktor pribadi, yang meliputi: sistem nilai yang dimiliki tiap-tiap individu, karakteristik kepribadian yang menyebabkan individu memiliki keunikan (idiosyncrasies) dan berbeda dengan individu yang lain. ${ }^{4}$

\section{Resolusi Konflik}

Resolusi konflik adalah sekumpulan teori dan penyelidikan yang bersifat eksperimental dalam memahami sifat-sifat konflik, meneliti strategi terjadinya konflik, kemudian membuat resolusi terhadap konflik”.

Melihat jenis konflik dan penyebab yang menyebabkan konflik itu terjadi, peneliti hendak mengajukan beberapa cara resolusi konflik yang mungkin dapat dipakai sebagai cara untuk menyelesaikan konflik tersebut, diantaranya:

a. Kompromi

Yaitu jalan tengah yang dicapai oleh pihak-pihak yang terlibat di dalam konflik.

b. Konsiliasi

Yaitu usaha untuk mempertemukan keinginan pihak-pihak yang berselisih sehingga tercapai persetujuan

\footnotetext{
4Alo, Liliweri, PRASANGKA \& KONFLIK: Komunikasi Lintas Budaya Masyarakat Multikultur, (Yogyakarta: LKiS Yogyakarta. 2005), 21-22.
} 
bersama. Disini akan ditempuh dengan cara mempertemukan kedua belah pihak pengurus Masjid Nurul Insan dan Masjid Nurul Ichsan untuk mencapai kesepakatan bersama.

\section{c. Integrasi}

Yaitu mendiskusikan, menelaah, dan mempertimbangkan kembali pendapat-pendapat sampai diperoleh suatu keputusan yang memaksa semua pihak. Ini adalah cara terkahir yang disajikan oleh peneliti. Akan dilaksanakan dengan cara mendiskusikan masalah ini dengan para pengurus masjid, ulama serta warga agar diperoleh keputusan yang akan ditaati oleh semua pihak. ${ }^{5}$

\section{Analisis Konflik Pembangunan Islamic Center dan Masjid At- Taqwa Mataram}

Konflik adalah bentuk perasaan yang tidak beres yang melanda hubungan antara satu bagian dengan bagian lain, satu orang dengan orang lain, satukelompokdengankelompok lain. ${ }^{6}$ Konflik dapat memberi dampak secara positif fungsional sejauh ia memperkuat kelompok dan secara

5 Musahadi, dkk. Mediasi Dan Resolusi Konflik di Indonesia: Dari Konflik Agama Hingga Mediasi Peradilan. (Semarang: WMC. 2007), 285.

6 Alo Liliweri, Sosiologi Organisasi, (Bandung: PT. Citra Aditya Bakti, 1997), 128. negatif fungsional sejauh ia bergerak melawan struktur. ${ }^{7}$

Secara etimologi, konflik (conflict) berasal dari bahasa latin configere yang berarti saling memukul. Konflik juga diartikan sebagai suatu tindakan salah satu pihak yang berakibat menghalangi, menghambat, atau mengganggu pihak lain di mana hal ini dapat terjadi antar kelompok masyarakat ataupun dalam hubungan antar pribadi. Hal ini sejalan dengan pendapat Morton Deutsch, seorang pionir pendidikan resolusi konflik yang menyatakan bahwa dalam konflik, interaksi sosial antar individu atau kelompok lebih dipengaruhioleh perbedaan daripada oleh persamaan. ${ }^{8}$ Sedangkan menurut Scannell, konflik adalah suatu hal alami dan normal yang timbul karena perbedaan persepsi, tujuan atau nilai dalam sekelompok individu.

Konflik tidak hanya terjadi dalam konteks fisik semata, tidak hanya melibatkan dua kelmpok yang memang secara mendasar berbeda, namun juga pada suatu kelompok tertentu yang diikat oleh kesamaan nilai atau paham (konflik

7 MargaretM.Poloma, SosiologiKontemporer, (Jakarta: Raja Grafindo Persada, 1994), 115.

8 Bunyamin Maftuh, Pendidikan Resolusi Konflik, (Jakarta: 2005), 47. 
intragroup). Dalam konteks agama Islam, konflik intraagama bukanlah sesuatu yang baru. Hal tersebut merupakan warisan sejarah panjang perkembangan agam Islam. Sejak dahulu telah terbentuk kelompokkelompok yang sama-sama memiliki paham yang berbeda, seperti syiah, murjiah, dan khawarij. Perbedaanperbedaan tersebut muncul sebagai akibat dari perbedaan cara penafsiran ajaran pokok agama yakni al-Quran dan al-Hadits. Oleh para ulama, perbedaan (khilafiyah) merupakan sunnatullah dan tidak perlu sampai menimbulkan konflik pada eskalasi pertentangan fisik.

Pembangunan sarana ibadah bagi umat Islam (masjid) adalah hal yang penting sebagai warisan dari ajaran rasulullah. Masjid sebagai rumah ummat adalah kebutuhan utama umat Islam dalam menjalankan berbagai macam aspek keagamaannya. Namun demikian pembangunan hajat bersama ini tidak terlepas dari eskalasi konflik internal, meskipun tidak seheboh konflik antar agama, namun hal ini menjadisalah satu yang perlu disoroti dalam eksistensi kehidupan umat Islam. Seperti yang akan dibahas dalam bab ini, terkait dengan konflik dan resolusi konflik pembangunan masjid yang berdekatan antara
Masjid Hubbul Wathan dengan Masjid Raya At-Taqwa mataram.

\section{Konflik Pemanfaatan Masjid At-Taqwa Mataram}

Masjid Raya At-Taqwa merupakan salah satu masjid yang berada di pusat Kota Mataram, dan telah lama digunakan oleh masyarakat sebagai sarana ibadah dan pemanfaatan lainnya. dengan diresmikannya Islamic Center NTB, timbul masalah mengenai status pemanfaatan masjid raya kedepannya.

Salah satu maslah yang timbul adalah tentang polemik dualisme pmanfaatan masjid antara Islamic Center NTB dengan Masjid Raya At-Taqwa. Polemik tersebut memunculkan persepsi yang beragam ditengah masyarakat terutama masyarakat Islam itu sendiri.

Salah satu tanggapan mengenai hal ini muncul dari kelompok jamaah tabligh yang memang telah lama "menguasai" Masjid Raya At-Taqwa Mataram sebagai pusat kegiatan dakwahnya. Meskipun segala kegiatan Masjid Raya AtTaqwa Mataram telah dipindahkan ke Islamic Center NTB, Masjid Raya At-Taqwa Mataram masih digunakan untuk beberapa kegiataan 
keagamaan yang dikelola oleh kelompok Jamaah Tabligh.

Hal demikian menimbulkan penilaian beragam dari masyarakat. Dulaisme pemanfaatan masjid sangat terasa. Di satu sisi pemerintah telah "mengosongkan" masjid raya dari segala kegiatan keagamaan dan dipusatkan keIslamic Center. Namun dilain pihak pula kelompok Jamaah Tabligh masih memanfaatakan Masjid Raya At-Taqwa Mataram. Alasan mereka sangat sederhana "selagi masih dapan di manfaatkan kenapa harus ditinggalkan".

Terkait dengan pemanfaatan Masjid Raya At-Taqwa Mataram kedepannya yang belum mendapat kejelasan dari pihak pemerintah memunculkan informasi liar yang berkembang di tengah-tengah masyarakat. Salah satu informasi yang berdar dan dhimpun oleh penulis adalah bahwa Masjid Raya At-Taqwa Mataram akan diratakan dengan tanah dan akan dijadikan kawasan perkantoran. Tentu saja apabila informasi yang demikian benar adanaya, maka tentu saja akan menimbulkankekecewaan daripihak pewakaf, karena awal kesepakatan dari penggunaan lahan tersebut diperuntukkan sebagai masjid.

9 Wawancara dengan salahsatu mantan pengelola Masjid Raya At-Taqwa Mataram
Pemerintah seharusnya memberi kejelasan yang pasti terkait pemanfaatan Masjid Raya At-Taqwa Mataram kedepannya sehingga tidak menimbulkan informasi liar berkembang. Pemerintah sejauh ini masihmelakukankomunikasidengan pihak pewakaf terkait status tanah Masjid Raya At-Taqwa Mataram dan hal tersebut memang perlu dilakukan secara intensif sehingga tidak menimulkan dari pihak-pihak yang merasa berkepentingan dan dirugikan dengan pemafaaatan masjid Masjid Raya At-Taqwa Mataram kedepannya.

Masjid Raya At-Taqwa Mataram merupakan salah satu masjid kebanggaan warga Kota Mataram sebelum dibangunnya Islamic Center NTB. Kini Masjid Raya AtTaqwa Mataram, meskipun secara pengelolaan telah ditarik oleh Pemerintah Kota Mataram dan masuk kedalam wilayah Integrasi Islamic Center NTB. Meskipun demikian, Masjid Raya At-Taqwa Mataram yang masih digunakan sampai saat ini oleh Jamaah Tablig, berada di bawah tanggung jawab UPT Islamic Center. UPT Islamic Center NTB menanggung biaya operasional Masjid Raya meskipun tidak ada dana yang dianggarkan 
oleh pemerintah Kota Mataram maupun Provinsi NTB.

Pengakuan akan adanya pembiayaan yang diberikan oleh UPT Islamic Center NTB terhadap biaya operasional Masjid Raya AtTaqwa Mataram menuaikontroversi, karena pada pihak lain bahwa ada pengakuan dari mantan pengelola Masjid Raya At-Taqwa Mataram yang mengatakan, tidak ada dana operasional yang dianggarkan baik oleh pemerintah Kota Mataram, Provinsi NTB dan bahkan oleh UPT Islamic Center.

Adanya klaim-klaim tersebut semakin mempertajam permasalahan, karena persoalan lama tentang pemanfaatan Masjid Raya At-Taqwa Mataram yang masih belum jelas, kemudian muncul lagi permasalahan lainnya. ${ }^{10}$ Jika persoalan tersebut ditelaah menggunakan teori konflik menurut Scannell, konflik adalah suatu hal alami dan normal yang timbul karena perbedaan persepsi, tujuan atau nilai dalam sekelompok individu, maka permasalahan tersebut memang terjadi karena adanya perbedaan persepsi, tujuan dan nilai dalam sekelompok individu dalam memahami pembangunan dan

10 Bunyamin Maftuh, Pendidikan Resolusi Konflik, (Jakarta: 2005), 47. pemanfaatn Masjid Hubbul Wathan / Islamic Center dengan Masjid AtTaqwa Mataram.

2. Konflik Pembangunan dan Pemanfaatan Masjid Hubbul Wathan Islamic Center

Di dalam hukum Islam, pembangunan fasilitas umum selalu berorintasi kepada kepentingan umat, dan pengkajian hukum terhadap realita di tengah masyarakat selalu menggunakan teori tujuan hukum Islam, yang pada prinsipnya bagaimana mewujudkankemanfaatandalam kehidupan di dunia maupun di akhirat. Tujuan mewujudkan „kemanfaatan $\square$ ini, sesuai dengan prinsip umum al-Qur'an ${ }^{11}$, sebagai mana dirumuskan dalam kaidah-kaidah ushul fiqh seperti:

a. Al-asl fi al-manafi al-hall wa $f i$ al-mudar al man'u (segala yang bermanfaat dibolehkan, dan segala yang mudarat dilarang).

b. La darara wa dirar (jangan menimbulkan kemudaratan dan jangan menjadi korban kemudaratan).

11 Achmad Ali, Menguak Teori Hukum (Legal Theory) dan Teori Peradilan (Judicialprudence) Termasuk Interprestasi Undang-Undang (Legisprudence),( Jakarta,: Kencana Prenada Media Group, 2009), 216. 
c. Ad-darar yuzal (bahaya harus dihilangkan).

Pembangunan masjid dan musholla mempunyai tujuan utama dari pembangunan tersebut, dimana pembangunan yang dilaksanakan adalah untuk kesejahteraan rakyat. Pembangunan sebuah masjid pada dasarnya memiiki tujuan pembangunan dari aspek pemberdayaan ummat. Pengadaan pembangunan masjid ataupun musholla merupakan sebuah pengharapan bersama seluruh umat Islam selaku bagian dari masyarakat bangsa ini.

Pembangunan rumah ibadah merupakan salah satu bentuk perwujudan dari penganut agama dalam rangka mewadahi penganut agama melaksanakan kegiatankegiatan agamanya. Pembangunan rumah ibadah merupakan salah satu bentuk kebebasan beragama dalam hal peribadatan keagamaan diatur dan dijamin dalam konstitusi negara indonesia.

Provinsi Nusa Tenggara Barat sebagai salah satu provinsi di Indonesia dengan mayoritas penduduknyaadalahMuslim. Namun demikian keadaan masyarakat NTB yang heterogen tidak berarti menghilangkan hak keberagaman kelompok lain (minoritas). Nuansa religiusitas masyarakat Muslim di NTB tercermin dari geliat pembangunan rumah ibadah (masjid) yang cukup pesat dan massif. Hampir di setiap sudut wilayah di NTB baik ditingkat kabupaten/ kota hingga tingkat desa/kelurahan banyak dijumpai bangunan masjid. Bahkan pada setiap sudut kampung terdapat masjid. Sehingga tidak heran Provinsi NTB khusunya pulau Lombok dikenal sebagai Pulau Seribu Masjid.

Ikon sebagai Pulau Seribu Masjid bukanlah sekedar julukan semata. Sebagai tambahan informasi, merujuk pada data bps 2014 mencatat bahwa ada 5.348 masjid yang ada di NTB, 3.882 ada di Pulau Lombok, 1.526 berada di Pulau sumbawa. Jika dibandingkan dengan data tahun 2010 terjadi peningkatan pembangunan masjid sebanyak 472 masjid dalam kurun waktu 4 tahun. ${ }^{12}$ Angka seribu hanyalah sebagai simbol untuk menunjukkan bangunan masjid di Pulau Lombok dan Sumbawa.

Adanya kegiatan pembangunan Islamic Center Provinsi NTB yang terletak di jalan Langko Kota Mataram, dinilai sebagai salah satu bentuksimbolisasi dan diproyeksikan

12 Sumber data Provinsi Nusa Tenggara Barat Dalam Angka Tahun 2016, 183. 
sebagai induk masjid-masjid yang ada di Provinsi NTB. Islamic Center NTB atau tepatnya Masjid Hubbul Wathan Islamic Center NTB mulai dibangun dengan tanda peletakan batu pertama oleh Gubernur NTB TGH. Muhammad Zainul Majdi pada 19 maret 2010 dan diresmikan penggunaannya pada akhir tahun 2013 tepatnya 15 desember 2013. Dibangun di atas tanah seluas 7,6 hektar dengan memakan waktu pembangunan kurang lebih 3 tahun dengan anggaran dana mencapai 600 milyar yang bersumber dari APBD, dana CSR perusahaan dan dana dari partisipasi masyarakat.

Adanya pembangunan Islamic Center NTB yang merupakan hajat semua pihak tidak terlepas dari masalah yang timbul. Niat baik pemerintah Provinsi NTB yang ingin membangun Islamic Center di Pusat Kota Mataram sebagai "landmark baru" dan juga diproyeksikan sebagai induk ribuan masjid di Pulau Lombok.

Terkait masalah ini timbul beragam persepsi ditengah-tengah masyarakat yang dapat berujung pada konflik vertikal antar golongan yang memiliki kepentingan maupun kelompok yang merasa dirugikan. Isu terciptanya lapangan pekerjaan bagi warga sekitar kawasan Islamic
Center, dualisme pemanfaatan masjid, dan juga status pemanfaatan Islamic Center NTB menjadi isu yang muncul di tengah-tengah masyarakat.

Banyak kalangan berharap dengan berdirinya Islamic Center NTB dapat meningkatkan kesejahteraan masyarakat dengan dengan pemanfaatan sumber daya manusia sekitar kawasan pembangunan. Pembangunan sebuah masjid pada dasarnya memiiki tujuan pembangunan dari aspek pemberdayaan ummat, tidak hanya dari segi religiusitas namun juga pada pengembangan dan peningkatan aspek ekonomi ummat.

Berdasarkan informasi dari kepala unit pengelola Islamic Center NTB, saat ini Islamic Center NTB masih belum mampu menyerap banyak tenaga kerja dari kalangan masyarakat sekitar, hal ini dikarenakan minimnya sdm profesional yang tersedia. Saat ini Islamic Center NTB hanya memiliki setidaknya 63 orang karyawan pengelola. Dari 63 orang tersebut terdiri dari satpan dan cleaning servis dan teknisi. Menurutnya jumlah pegawai tersebut masih jauh jika dibanding dengan Islamic Center dikawasan lain yang telah memiliki 
karyawan penegelola dengan bilangan ratusan orang. Jumlah yang demikian tidak sebanding dengan luas kawasan Islamic Center NTB yang memiliki luas 7,5 hektare. ${ }^{13}$ Namun sayangnya dari jumlah pegawai Islamic Center NTB yang ada belum sepenuhnya menyerap sumberdaya manusia di sekitar kawasan Islamic Center NTB seperti warga dari kawasan Dasan Agung tepat berada di samping Islamic Center NTB. Meskipun tanah lokasi pembangunan milik pemerintah, namun masyarakat sekitar juga perlu diperhatikan sebagai masyarkat yang memiliki andil terhadap kesuksesan pembangunan Islamic Center. Tanpa peran masyarakat sekitar, bagaimanapun usaha pemerintah dalam melakukan pembangunan tidak mungkin akan terwujud dengan baik.

Masalah lain yang muncul adalah adanya persepsi dualisme pemanfaatan masjid antara Masjid Raya Hubbul Wathan Islamic Center NTB dengan Masjid Raya AtTaqwa Mataram. Setelah diresmikan pemanfaatan dan penaggunaan Islamic Center NTB oleh Pemerintah Provinsi NTB terhadap Masjid Raya At-Taqwa Mataram tidak lagi

13 H. Abd. Mukti, wawancara, Mataram, 12 Juli 2017. difungsikan sebagai sarana rumah ibadah. Namun pada kenayataannya Masjid Raya masih digunakan sebagai tempat berkumpulnya Jamaah Tabligh. Para anggota Jamaah Tabligh (salafi wahabi) masih memanfaatakan Masjid Raya At-Taqwa Mataram sebagai lokasi melaksanakan kegiatan halaqahhalaqah dan kegiatan lainnya. Status pengelolaan Masjid Raya At-Taqwa Mataram belum meiliki kejelasan dari Pemerintah Provinsi NTB. Alasan inilah yang kemudian membuat Jamaah Tabligh masih memanfaatkan Masjid Raya AtTaqwa Mataram.

Selain itu Jamaah Tabligh yang berada di Masjid At-Taqwa Mataram enggan berpindah ke Masjid Hubbul Wathan Islamic Center. Bahkan mereka (Jamaah Tabligh) mengkritik keras pemanfaatan Islamic Center yang dimanfaatkan sebagai kawasan pariwisata yang bebas dimasuki bagi siapapun. Bagi mereka seharusnya masjid digunakan sebagai mana peruntukkannnya, bukan sebagai sarana yang patut disamakan dengan kawasan pariwisata lainnya, karena hal tersebut bertentangan dengan ajaran Islam. Meskipun kritikan mereka tersebut tidak dimunculkan keranah publik, dengan keengganan mereka berpindah ke masjid Islamic 
Center sebagai salah satu bentuk protes.

Di sisi lain, pengelola Islamic Center sendiri pada kenyataannya membatasi aktivitas para Jamaah Tabligh untuk melaksanakan kegiatannya di Islamic Center. Pengurus Islamic Center berdalih bahwa pemahaman yang "berbeda" antara kebanyakan masyarakat Islam dengan kelompok Jamaah Tabligh menjadi salah satu alasannya. Istilah "ngecamp" yang akarab bagi Jamaah Tabligh juga menjadi salah satu dalih bagi pengelola Islamic Center untuk menolak pengelolaan Islamic Center oleh Jamaah Tabligh. Alasan penolakan tersebut Ditakutkan oleh pengelola apabila para Jamaah Tablig masuk ke Islamic Center maka akan terjadi seperti di Masjid Raya AtTaqwaMataram, dimanaparaJamaah Tabligh memanfaatkan Masjid Raya sebagai tempat berkumpul namun tidak mengindahkan kebersihan dari lokasi masjid, sehingga saat ini Masjid Raya ada kesan kumuh yang melingkupinya.

Diakui oleh pengelola Islamic Center, meskipun pengelola Masjid Raya telah ditarik oleh Pemerintah Kota Mataram, pengelola Islamic Center mengambil alih tanggung jawab pengelolaan Masjid Raya AtTaqwa Mataram, meskipun tidak ada anggaran oleh Pemerintah Daerah maupun Pemerintah Kota Mataram bagi pengelolaan Masjid Raya At-Taqwa mataram.

Selain itu juga, muncul masalah mengenai ketidak mampuan pemerintah mengenai tata kelola wilayah pemabangunan Islamic Center yang dibangun persis disebelah Masjid Raya At-Taqwa Mataram sehingga menghilangkan fungsi Masjid Raya At-Taqwa Mataram sebagai masjid yang sudah cukup lama berdiri di Kota Mataram. Ada beberapa pertanyaan dari masyarakat yang mempertanyakan permasalahan lokasi pembangunan Islamic Center, terutama ketika pembangunan tersebut mengambil lokasi di tengah kota. Ada sejumlah masyarakat yang menyarankan bahwa seharusny pemerintah memilih tempat yang lain di areal Kota Mataram, sehingga tidak menghilangakn fugsi Masjid Raya At-Taqwa Mataram. Bahakan ada juga yang mengatakan pembangunan Islamic Center sebagai simbol kontestasi keberagaman di Kota Mataram yang heterogen. Pembangunan Islamic Center dinilai sebagai bentuk kontestasi keagamaan dengan tidak memperhatikan kelompok minoritas lainyya. Bahkan ada 
aganggapan bahwa Islamic Center adalah kontestasi antara Muslim dengan Hindu di Kota Mataram, yang juga diktegorikan sebagai kelompok mayoritas kedua. Dengan adanya pembanguna isamic center pemprov NTB ingin menunjukkan bahwa Kota Mataram adalah kota yang religius namun dari satu sudut pandang dimana religius berarti menjadi lebih Islami tanpa melihat unsur-unsur nilai gama ataupun kelompok lain.

$\begin{array}{rrr}\text { Keberadaan } & \text { Islamic } & \text { Center } \\ \text { pada suatu } & \text { kondisi } & \text { sosial }\end{array}$
masyarakat, terlebih masyarakat NTB yang heterogen tentu saja tidak terlepas dari masalah pro dan kontra terutama ketika ada sekelompok sosial masyarakat yang merasa "dirugikan". Suksesnya pembangunan Islamic Center NTB dinilai pula oleh sebagian kelompok masyarakat sebagai sebuah kesuksesan pemerintah NTB dalam menampung aspirasi masyarakatnya yang mayoritas adalah Muslim, terlebih Provinsi NTB "kebetulan" dipimpin oleh seorang Tuan Guru yang merupakan sebuah status sosial yang memiliki legitimasi kuat ditengah-tengah masyarakat NTB.

\section{Resolusi Konflik Islamic \\ Center dan Masjid At-Taqwa \\ Mataram}

Resolusi konflik yang dalam bahasa Inggris adalah conflict resolution memiliki makna yang berbeda-beda menurut para ahli yang fokus meneliti tentang konflik. Resolusi dalam Webster Dictionary menurut Levine adalah (1) tindakan mengurai suatu permasalahan, (2) pemecahan, (3) penghapusan atau penghilangan permasalahan. ${ }^{14}$

$\begin{array}{cr}\text { Sedangkan } & \text { Weitzman } \\ \text { mendefinisikan resolusi konflik }\end{array}$ sebagai sebuah tindakan pemecahan masalah bersama (solve a problem together). Lain halnya dengan Fisher yang menjelaskan bahwa resolusi konflik adalah usaha menangani sebab-sebab konflik dan berusaha membangun hubungan baru yang bisa tahan lama di antara kelompokkelompok yang berseteru.

Menurut Mindes resolusi konflik merupakan kemampuan untuk menyelesaikan perbedaan dengan yang lainnya dan merupakan aspek penting dalam pembangunan sosial dan moral yang memerlukan keterampilan dan penilaian untuk

14 Levine, Webster Dictionary, (1998), 3. 
bernegoisasi, kompromi serta mengembangkan rasa keadilan. ${ }^{15}$

Dari pemaparan teori menurut para ahli tersebut, maka dapat ditarik kesimpulan bahwa yang dimaksud dengan resolusi konflik adalah suatu cara individu untuk menyelesaikan masalah yang sedang dihadapi dengan individu lain secara sukarela. Resolusi konflik juga menyarankan penggunaan cara-cara yang lebih demokratis dan konstruktif untuk menyelesaikan konflik dengan memberikan kesempatan pada pihak-pihak yang berkonflik untuk memecahkan masalah mereka oleh mereka sendiri atau dengan melibatkan pihak ketiga yang bijak, netral dan adil untuk membantu pihak-pihak yang berkonflik memecahkan masalahnya.

\section{Analisis Resolusi Konflik Pemanfaatan Masjid At-Taqwa Mataram}

Sesuai dengan master plan pembangunan Islamic Center NTB, kawasan Islamic Center yang mencapai 7,5 hektare juga termasuk di dalamnya Masjid Raya At-Taqwa Mataram sebagai kawasan intergral dari kawasan terpadu Islamic Center NTB. Kedepannya Masjid Raya At-

15 Wisnu Suhardono, "Konflik dan Resolusi" dalam https: / / www.academia.edu/15116981
Taqwa Mataram akan diproyeksikan sebagai museum kebudayaan Islam, pusat kajian nilai-nilai Islam terpadu serta tetap akan digunakan sebagai tempat ibadah.

Realisasi pengembangan Masjid At Taqwa Mataram saat ini telah diwujudkan dengan menggunakan anggaran tahun 2018. Masjid AtTaqwa Mataramakan dikembangkan menjadi bangunan bertingkat tiga sebagaimana yang tertera pada master plan. Tingkat pertama rencananya akan tetap dipungsikan sebagai tempat ibadah sesuai dengan peruntukan sebagaimana mestinya. Pada tingkat dua akan dijadikan pusat pengembnagn nilai Islam terpadu serta museum kebudayaan Islam pada tingkat yang terakhir.

Terkait dengan status wakaf tanah, pihak pemda saat ini masih melakukan komunikasi itensif dengan pihak pewakaf supaya tidak menimbulkan kesalah pahaman dari kalangan keluarga pewakaf. Status tanah Majid Raya At-Taqwa merupakan tanah wakaf yang diperuntukkan bagi pembangunan masjid.

Sejak dahulu Masjid Raya AtTaqwa Mataram telah menjadi pusat dakwah bagi sekelompok Jamaah Tabligh. Berkembang persepsi dikalangan masyarakat bahwa 
masjid raya dikuasai dan menjadi markaz utama jamaah tabligh di kota mataram. Setiap harinya Masjid Raya At-Taqwa mataram digelar acara halaqah-halaqah oleh Jamaah Tabaligh. Namun persoalan timbul setelah Masjid Raya tidak lagi diungsikan sebagai sarana masjid. oleh kerena itu pemerintah penting juga untuk memikirkan "relokasi" Jamaah Tabligh yang telah lama memanfaatkan Masjid Raya AtTaqwa Mataram sehingga tidak ada pihak yang merasa dirugikan terkait pemanfaatan Masjid Raya At-Taqwa kedepannya.

\section{Analisis Resolusi Konflik Pembangunan dan \\ Pemanfaatan Masjid Hubbul Wathan Islamic Center}

Konflik merupakan sebuah konsekuensi logis dari sebuah interaksi di antara dua pihak. Ada beberapa hal yang bisa menjadi alasan berkonflik. Di antaranya adalah masalah ketimpangan yang menimbulkan kecemburuan terhadap pihak tertentu, yang meliputi ketimpangan sosial, ekonomi, budaya dan agama.

Seperti yang telah dibahas sebelumnya, dengan adanya pemabangunan Islamic Center NTB tidak hanya sebagai sarana pemberdayaan religiusitas masyarakat, namun juga komponen lain dalam kehidupan sosial masyarakat, salah satunya adalah pemberdayaan dalam bidang ekonomi masyarakat terutama sekitar kawasan pembangunan Islamic Center NTB melalui penyerapan sumber daya manusia.

Konflik sosial masyarakat meruapakan konflik komunal yang sering terjadi, dengan berbagai faktor penyebabnya. Seringkali konflik tersebut muncul disebabkan karena kecemburuan sosial yang didalangi oleh taraf ekonomi masyarakat. Dalam konteks ini, pembangunan Islamic Center NTB memang mampu menyerap tenaga kerja. namun kenyataan dilapangan penyerapan tenaga kerja sepenuhnya belum mampu menyerap tenaga kerja dari kalangan masyarakat sekitar.

Dilematisasi muncul dari pihak pemerintah selaku inisiator pembangunan Islamic Center NTB. Harapan dengan adanya Islamic Center sebagai sarana lapangan pekrjaan bagi masyarakat, namun kenyataan masyarakat sekitar kawasan belum memiliki SDM yang mumpuni, belum memenuhi standar untuk bekerja menjadi pengurus di kawasan Islamic Center NTB. 


\begin{abstract}
Pemerintah NTB sebagai stakeholders terkait perlu memikirkan solusi yang winwin solution sebagai satu langkah antisipasi timbulnya konflik komunal berlatar belakang kecemburuan ekonomi. Komunikasi yang baik perluditerapkan PemerintahProvinsi kepada masyarakat sekitar sehingga tidak timbul kesalah pahaman terkait masalah ini.
\end{abstract}

Pemanfaatan kawasan Islamic Center sebagai kawasan terpadu terhadap pengembangan syiar dakwah Islamiyah hatus diimbangi dengan kesiapan masyarakat sebagai pemain utama dalam percaturan kehidupan sosial yang timbul akibat pembangunan kawasan terpadu Islamic Center NTB.

Pembangunan Islamic Center NTB, tidak hanya sebagai simbol keagamaan di ruang publik yang dapat menimbulkan kecemburuan bagi kelompok etnis agama minoritas. Masifnya pembangunan kota berbasis religiusitas yang terkadang salah diartikan oleh sebagian pihak, yang mana religius terkadang diartikan menjadi lebih Islami. Nilai-nilai non Islami terkadang bukan dianggap sebagai nilai religius. Islamic Center yang memang digadang sebagai induk masjid dipulau Seribu Masjid, tidak hanya sebagai servis terhadap nuansa keberagaman di NTB. Namun juga harus diimbangi dengan penerapan nilai-nilai rahmatan lil alamin bagi segenap masyarakat NTB.

Jika melihat perkembangan pembangunan khususnya di Kota Mataram, model penagunan tatakota lebih mengarah pada pemunculan simbol-simbol nilai agama Islam. Jika melihat dibebarapa sudut Kota di Mataram banyak ditemukan simbol-simbol bernuansa Islam. Hal ini menjadi titik rawan terhadap munculnya konflik sosial ditengah masyarakat yang heterogen.

Muncul persepsi ditengah masyarakat bahwa pembangunan Islamic Center NTB sebagai sebuah dominasi kelompok mayoritas yang didukung oleh pemerintah dan mengesampingkan aspirasi kelompok lain. Satu kelompok merasa diuntungkan sedangkan sebagian kelompok lain dirugikan. Hal tersebut tentu saja menciderai niatan baik sebuah proses pembangunan fasilitas keagamaan yang seharusnya dapat diterima dengan lapang dada bagi segenap masyarakat NTB.

Pemanfaatan Islamic Center sebagai salah satu spot wisata syariah di NTB tentu menimbulkan pro kontra ditengah masyarakat 
NTB. Ada sekelompok masyarakat yang mendukung dan ada juga yang menolak wacana tersebut. Konflik internal agama pun muncul terkait dengan masalah ini.

Mayoritas Muslim di NTB adalah pemeluk Islam yang dewasa ini punya banyak nama, ada yang menyebutnya Islam indonesia, Islam nusantara yang lebih ekstrim menyebutnya sebagai Islam sinkretik. Jika dicermati daripelaksanaan ritualritual agama Islam yang berkembang ditengah masyarakat adalah Islam yang telah membaur dengan konsepkonsep adat positif yang berkebnag ditengah masyarakat NTB. Segenap masyarakat NTB memberi jempol terhadap kesuksesan pemerintah memabangun Islamic Center NTB. Namun kritikan muncul dari segenap kelompok Islam yang menggaungkan konsep pembaruan atau oleh masyarakat banyak dikenal sebagai kelompok Jamaah Tabligh dengan paham salafi wahabi.

Meskipun tidak muncul gagasan yang mengandung kritikan muncul diruang-ruang publik, kelompok terakhir ini memberi kritik pedas terkait pemanfaatan Islamic Center sebagai sarana pariwisata. Ada sekelompok orangyang memandang bahwa sarana rumah ibadah sebagai masjid harus difungsikan sebagaimana fungsinya pada zaman Nabi Muhammad. Kelompok tersebut menilai pembangunan Islamic Center yang didukung penuh oleh Pemerintah Provinsi NTB memiliki agenda lain. Pemerintah dinilai cenderung mengikuti selera pasar yang berkembang dengan megorbankan kepentingan ummat.

Perbedaan cara pandang seperti diatas adalah suatu kewajaran yang muncul dari perbedaan pemahaman antar kelompok terhadap realita yang berkembang di era modern ini. Yang terpenting adalah bagaimana pemerintah memainkan peran meluruskan niatan baik tersebut, jangan sampai niatan membangun rumah ummat justru menimbulkan tanggapan negatif dari ummat itu sendiri.

\section{E. Penutup}

Konflik pada umumnya selalu melahirkan berbagaimacam persoalan, sebagaimana teori yang disampaikan oleh Scannell, konflik adalah suatu hal alami dan normal yang timbul karena perbedaan persepsi, tujuan atau nilai dalam sekelompokindividu. Bahkan konflik tidak hanya terjadi dalam konteks fisik semata, tidak hanya melibatkan dua kelmpok yang memang secara mendasar berbeda, namun juga 
pada suatu kelompok tertentu yang diikat oleh kesamaan nilai atau paham (konflik intragroup). Termasuk masalah yang timbul yang disebabkan oleh polemik dualisme pmanfaatan masjid antara Islamic Center NTB dengan Masjid Raya AtTaqwa Mataram, diantaranya adalah munculnya persepsi yang beragam ditengah masyarakat terutama masyarakat Islam khususnya di Kota Mataram.

Berbagai macam persepsi tersebut mengenai hal ini muncul dari kelompok Jamaah Tabligh yang memang telah lama "menguasai" Masjid Raya At-Taqwa Mataram sebagai pusat kegiatan dakwahnya. Meskipun segala kegiatan Masjid Raya At-Taqwa Mataram telah dipindahkan ke Islamic Center NTB, Masjid Raya masih digunakan untuk beberapa kegiataan keagamaan yang dikelola oleh kelompok Jamaah Tabligh. Pembangunan rumah ibadah sewajarnya berorintasi kepada kepentingan umat, yang pada prinsipnya bagaimana mewujudkan kemanfaatan dalam kehidupan di dunia maupun di akhirat, bukan sebaliknya sebuah pembangunan kemudian menafikan kelompok minoritas.

Resolusi Konflik Terhadap Konflik dalam hal pemanfaatan
Masjid At-Taqwa Mataram. Realisasi pengembangan Masjid At Taqwa Mataram menunggunakan anggaran tahun 2018.

Masjid At Taqwa Mataram akan dikembangkan menjadi bangunan bertingkat tiga. Tingkat pertama rencananya akan tetap dipungsikan sebagai tempat ibadah sesuai dengan peruntukan sebagaimana mestinya. Pada tingkat dua akan dijadikan pusat pengembnagn nilai Islam terpadu serta museum kebudayaan Islam pada tingkat yang terakhir.

Terkait dengan status wakaf tanah, resolusi terhadap konflik tersebut berusaha diurai. Upayaupaya menemukan resolusi terhadap konflik tersebut nampak dilakukan oleh Pemerintah, baik kota maupun provinsi dengan cara melakukan komunikasi itensif dengan pihak pewakaf supaya tidak menimbulkan kesalah pahaman dari kalangan keluarga pewakaf. Status tanah Majid Raya At-Taqwa merupakan tanah wakaf yang diperuntukkan bagi pembangunan masjid. 


\section{Daftar Pustaka}

A. Rahman

Asyumi, Ilmu

Fiqih. Jakarta:

Proyek

Pembinaan Prasarana dan

Sarana Perguruan Tinggi

Agama Islam/IAIN di Jakarta

Direktorat Jenderal Pembinaan

Kelembagaan Agama Islam

Departemen Agama, 1986

Alo Liliweri, Prasangka \& Konflik:

Komunikasi

Lintas Budaya Masyarakat Multikultur (Yogyakarta: LKiS Yogyakarta. 2005)

Joko P Subagyo. Metode Penelitian dalam Teori dan Praktek. (Jakarta: Rieneka Cipta, 1997)

Kartini Kartono. Pengantar Metodologi

Riset Sosial. (Bandung: Alumni, 1986)

M.B. Miles dan A.M. Huberman, "Analisis Data Kualitatif", (Jakarta: UI-Press, 1992)
Muhammad Abid Al-Kabisi

Abdullah, Hukum Wakaf.

Kajian Kontemporer Pertama dan Terlengkap Tentang Fungsi dan Pengelolaan Wakaf serta Penyelesaian Atas Sengketa Wakaf. Ahkam Al-Waqf fi AlSyariah Al-Islamyiah. terj. Ahrul Sani Faturrahman (Depok: IIMoN Press, 2004)

Musahadi, dkk. Mediasi Dan Resolusi Konflik Di Indonesia: Dari Konflik Agama Hingga Mediasi Peradilan. (Semarang: WMC. 2007)

Rozi Syafuan, dkk. Kekerasan Komunal: Anatomi dan Resolusi Konflikdi Indonesia (Yogyakarta: Pustaka Pelajar, 2006)

Suharsini Arikunto. "Prosedur Penelitian", (Jakarta: Rieneka Cipta ,1998)

Sutrisno Hadi. "Metodologi Research Jilid II", (Yogyakarta: Yayasan Penerbitan Psikologi UGM, 1973) 